\title{
TANULÁSI UTAK A KÖZOKTATÁSBAN ÉS A FELSŐOKTATÁSBAN
}

\author{
FEHÉRVÁRI ANIKÓ ${ }^{a, *}$ - SZEMERSZKI MARIANNA ${ }^{b}$ \\ ${ }^{a}$ ELTE Neveléstudományi Intézet \\ ${ }^{b}$ EKE-Oktatáskutató és Fejlesztő Intézet
}

A tanulmány nemzetközi összefüggésben bemutatja azokat a továbbhaladással összefüggő trendeket és megközelítéseket, amelyek a kétezres évek eleje óta jelen vannak a magyar oktatásban. Kiemelten foglalkozik a lemorzsolódás, korai iskolaelhagyás jelenségével, azok oktatáspolitikai vetületével, valamint a tanulók, szülők továbbtanulási preferenciáival. Emellett az írás kitér a felsőoktatási trendekre, változásokra, hogyan alakult a felsőoktatáshoz való hozzáférés az ezredforduló óta, illetve milyen tipikus mintázatai vannak a felsőfokú továbbtanulásnak, a képzésben való továbbhaladásnak. A tanulmány foglalkozik a felsőfokú tanulmányok melletti kitartás és a lemorzsolódás jelenségének vizsgálati lehetőségeivel is.

Kulcsszavak: közoktatás, felsőoktatás, tanulási utak, képzésben való részvétel

There have been many changes in developed countries in the last decades that have an impact on learning paths. This study focuses on the trends of learning pathways in Hungary since the early 2000s in an international context. It identifies the phenomenon of early school leaving and dropout, their educational policy implications and observes students' and parents' preferences. In addition, the paper discusses trends and changes in higher education, how access to higher education has evolved since the turn of the millennium and describes the typical patterns of tertiary education. Persistence in higher education and the phenomenon of drop-out are also discussed.

Keywords public education, higher education, learning paths, enrolment rate in education

* Levelező szerző: Fehérvári Anikó, ELTE PPK, 1075 Budapest, Kazinczy u. 23-27.

E-mail: fehervari.aniko@ppk.elte.hu 


\section{Bevezetés, elméleti kitekintés}

A z elmúlt évtizedekben számos olyan változás következett be a fejlett országok fiataljait illetően, amelyeket együttesen az ifúsági korszakváltás fogalommal illethetünk. Ennek egyik fontos tényezője az oktatás expanziója, amelynek következtében meghosszabbodik az ifjúsági életszakasz, és megváltozik annak szerkezete. A fiatal felnőttkor különféle életeseményei egyrészt idősorrendjüket tekintve is változnak (előbbre kerülnek vagy kitolódnak), másrészt az egymást követő életesemények lineáris láncolata helyett leginkább az egymást időszakosan váltó vagy egymással párhuzamosan futó, egymásba csúszó életesemények válnak tipikussá. Úgy is mondhatnánk, hogy a korábbi „vagy-vagy” kategóriák helyett az „is-is” kategóriák írják le leginkább a fiatalkori élethelyzeteketः a munka világába való bekapcsolódás részben korábban elkezdődik (diákmunkák), részben bonyolultabbá válik (oda-vissza mozgások jellemzik), s a tanulási utak sem zárulnak le véglegesen egy adott életkorban (Zinnecker 1993; Gábor 2004; Gábor 2012; Jancsák 2013; Somlai 2010).

Napjainkra a tanulással töltött idő jelentősen meghosszabbodott, a fejlett országok többségében egy adott korosztály túlnyomó többsége legalább 17 éves koráig ül az iskolapadban, de nagyon sokan azt követően is. A legtöbb európai országban növekszik azoknak az aránya, akik 20-29 éves korukban is részt vesznek valamilyen közép-vagy felsőfokú képzésben. Az 1. táblázat adatai jól mutatják, hogy a 20 éves koruk felett is tanulmányokat folytató fiatalok aránya az utóbbi 7 évben tovább nőtt, egyes országokban a 25-29 év közötti fiatalok negyede-ötöde még mindig tanulmányokat (is) folytat.

\section{Közoktatási trendek}

A fentebb felvázolt trendek a magyar közoktatásban is tetten érhetők, ugyanakkor ezek a folyamatok 2009-től megtörtek, így két szakaszra bonthatjuk a rendszerváltástól napjainkig terjedő időszakot: az első szakaszt, a rendszerváltástól 2009-ig képzési expanzió és a tanulási idő megnövekedése jellemezte, majd 2009-től napjainkig a tanulási idő csökkenése mellett a képzésben részt vevők arányának csökkenése is megfigyelhető.

$\mathrm{Az} \operatorname{OECD}(2008,2019)$ adatgyüjtése alapján látható (1. táblázat), hogy Magyarországon 1995-ben a 15-19 éves korosztályon belül a fiatalok 64\%-a ült iskolapadban, ez az arány öt év alatt 14\%-kal növekedett, majd 2010-ig ugyanennyivel gyarapodott, az intenzív, majd elnyújtott növekedést követően viszont csökkenésnek indult. Az OECD (2019) legutolsó adatgyüjtése szerint jelenleg az említett korosztály $84 \%$-a van jelen az oktatásban. Az OECD-országok átlaga ugyanennyi, míg az Unió átlaga ennél magasabb, 88\%. A közép-európai tendenciákat tekintve azt tapasztaljuk, hogy a csehek adatai hasonlóan alakulnak, de 2010 után is megtartják a magas közoktatási részvételi arányt. Lengyelország esetében az érzékelhető, hogy magasabb rátával rendelkeztek már a kilencvenes években is, mint Magyarország, de csak 2010 után növekedett jelentősen a képzésben részt vevők aránya, ami jelenleg Csehország rátájához hasonlatos. A visegrádi országok negyedik országáról keveset tudunk, mivel nincs hivatalos OECD EAG adata, csak a 2017-es évről, ami viszont a magyaréhoz hasonló. Vagyis elmondható, hogy míg a cseh és lengyel középfokú oktatás a bővülés tendenciáját megtartotta, addig a magyar és a 
1. táblázat: Az adott korosztályból közép-vagy felsőfokon tanulók aránya az EU-tagországokban (\%), 1995, 2000, 2005, 2010 és 2017. Forrás: Education at a Glance 2019. OECD - Table B1.1., 2008. OECD Table C2.2.

\begin{tabular}{|c|c|c|c|c|c|c|c|c|c|c|c|c|c|}
\hline \multirow[b]{2}{*}{$\begin{array}{r}\text { Korosztályok } \\
\text { (év) }\end{array}$} & \multicolumn{3}{|c|}{2017} & \multicolumn{3}{|c|}{2010} & \multicolumn{3}{|c|}{2005} & \multicolumn{2}{|c|}{2000} & \multicolumn{2}{|c|}{1995} \\
\hline & $\begin{array}{l}2 \\
\stackrel{1}{1} \\
2\end{array}$ & $\begin{array}{l}\stackrel{+}{N} \\
\stackrel{\lambda}{1}\end{array}$ & $\begin{array}{l}\text { ָे } \\
\text { ป̂े }\end{array}$ & $\begin{array}{l}2 \\
1 \\
1 \\
-1\end{array}$ & $\begin{array}{l}\stackrel{+}{N} \\
\text { ô }\end{array}$ & $\begin{array}{l}\text { సे } \\
\text { ฝे }\end{array}$ & $\begin{array}{l}2 \\
1 \\
1 \\
-1\end{array}$ & $\begin{array}{l}\stackrel{+}{N} \\
\text { I }\end{array}$ & 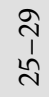 & $\begin{array}{l}2 \\
+1 \\
n\end{array}$ & $\begin{array}{l}\text { ָे } \\
\text { 1े } \\
\text { ते }\end{array}$ & $\begin{array}{l}2 \\
\stackrel{1}{1} \\
2\end{array}$ & $\begin{array}{l}\text { సे } \\
\text { ì }\end{array}$ \\
\hline Ausztria & 78 & 34 & 18 & 78 & 33 & 17 & - & - & - & 77 & 18 & 75 & 16 \\
\hline Belgium & 95 & 49 & 14 & 92 & 52 & 17 & 94 & 42 & 15 & 91 & 25 & 94 & 24 \\
\hline Csehország & 91 & 41 & 10 & 91 & 39 & 11 & 91 & 34 & 10 & 81 & 14 & 66 & 10 \\
\hline Dánia & 86 & 54 & 30 & 85 & 49 & 27 & - & - & - & 80 & 35 & 79 & 30 \\
\hline $\begin{array}{l}\text { Egyesült } \\
\text { Királyság }\end{array}$ & 85 & 31 & 10 & 76 & 27 & 10 & - & - & - & 75 & 24 & 72 & 18 \\
\hline Észtország & 89 & 39 & 15 & 91 & 44 & 14 & 91 & 40 & 14 & - & - & - & - \\
\hline Finnország & 86 & 51 & 31 & 87 & 53 & 31 & 87 & 55 & 30 & 85 & 38 & 81 & 28 \\
\hline Franciaország & 86 & 37 & 7 & 84 & 34 & 6 & 84 & 32 & 7 & 87 & 19 & 89 & 19 \\
\hline Görögország & 86 & 52 & 20 & - & - & - & - & - & - & 82 & 16 & 62 & 13 \\
\hline Hollandia & 93 & 54 & 18 & 90 & 47 & 12 & - & - & - & 87 & 22 & 89 & 21 \\
\hline Írország & 93 & 44 & 12 & 91 & 32 & 9 & 89 & 32 & 10 & 81 & 16 & 79 & 14 \\
\hline Lengyelország & 93 & 50 & 11 & 84 & 11 & 2 & 85 & 12 & 3 & 84 & 24 & 78 & 16 \\
\hline Lettország & 93 & 45 & 16 & 94 & 44 & 11 & - & - & - & - & - & - & - \\
\hline Litvánia & 94 & 47 & 13 & 98 & 56 & 16 & 98 & 49 & 17 & - & - & - & - \\
\hline Luxemburg & 76 & 20 & 7 & - & - & - & - & - & - & 74 & 5 & 73 & - \\
\hline Magyarország & 84 & 36 & 11 & 92 & 41 & 11 & 87 & 38 & 13 & 78 & 19 & 64 & 10 \\
\hline Németország & 87 & 48 & 21 & 89 & 45 & 17 & 88 & 41 & 18 & 88 & 24 & 88 & 20 \\
\hline Olaszország & 85 & 36 & 12 & 85 & 35 & 11 & 82 & 33 & 10 & 72 & 17 & - & - \\
\hline Portugália & 89 & 37 & 10 & 85 & 37 & 14 & 74 & 35 & 12 & 71 & 22 & 68 & 22 \\
\hline Spanyolország & 87 & 49 & 16 & 82 & 37 & 12 & 78 & 34 & 11 & 77 & 24 & 73 & 21 \\
\hline Svédország & 91 & 44 & 27 & - & - & - & - & - & - & 86 & 33 & 82 & 22 \\
\hline Szlovákia & 83 & 32 & 7 & - & - & - & - & - & - & - & - & - & - \\
\hline Szlovénia & 93 & 60 & 13 & 94 & 54 & 16 & 93 & 50 & 17 & - & - & - & - \\
\hline $\begin{array}{l}\text { EU23/EU19 } \\
\text { átlagérték }\end{array}$ & 88 & 43 & 15 & 88 & 41 & 14 & - & - & - & 81 & 22 & 77 & 19 \\
\hline
\end{tabular}

szlovák a szúkülés irányába mutat. Ha az Európai Unió többi országát nézzük, akkor ezzel a részvételi aránnyal Ausztria és Luxemburg mellett az utolsók között vagyunk. A z említett két országban a hagyományos szakmunkásképzés megtartása már évtizedek óta jellemző, vagyis ennek köszönhetően, e két országban alig változott húsz év alatt a 15-19 éves kohorsz részvétele az oktatásban. A többi európai országra viszont a folyamatos bővülés jellemző, vagyis egyre nagyobb az oktatásban való részvételi arány a 15-19 éves korosztályban. Nyilván e nyitás mögött a felsőoktatás bővülése is áll, hiszen a csaknem teljes körű középfokú oktatás biztosítja a felsőoktatás rekrutációs bázisát. 
Magyarországon tehát a rendszerváltástól kezdve 2009-ig a középiskolás korosztály egyre nagyobb aránya vett részt képzésben egyre hosszabb ideig. A képzési idő növekedése több tényező együttes hatásának köszönhető. Így megfigyelhető egy-egy képzési forma képzési idejének bővülése, pl. a kilencvenes években a szakközépiskolai képzésben a Világbanki Program (Tót 1996) a korábbi négyről öt évre emelte a képzés idejét, továbbá a két tanítási nyelvű középiskolák képzési ideje szintén öt év. 1998-tól pedig megkezdődött a hagyományos szakmunkásképzés átalakítása, és a korábbi hároméves képzés helyett $2+2$ évre változott a képzési idö ${ }^{1}$. A kétezres években is folytatódott a képzési idő expanziója, a nyelvi előkészítő képzés ${ }^{2}$ bevezetése (2004-től), amely szakközépiskolában és gimnáziumban egyaránt megvalósulhatott, szintén öt évre növelte a képzési időt, valamint az Arany János Programban (2000-től) is öt évig tanulnak a diákok. A képzési típusok átalakulása mellett tovább növelte a képzésben részt vevők arányát az is, hogy a szakmunkásképzést egyre kevesebb fiatal választotta, és egyre többen kívántak érettségit adó képzésekben tanulni. A képzési idő növekedése mellett a 18 éves korig tartó tankötelezettség ${ }^{3}$ is a magasabb életkor felé tolta ki a képzésben részt vevők számát. Kutatások bizonyítják, hogy föként az alacsony státuszú családok gyermekei számára jelentett megtartó eröt ez a rendelkezés (Adamecz-Völgyi 2018).

A második szakasz 2009-ben, az előrehozott szakképzés bevezetésével indult ${ }^{4}$. Ez volt az első lépés, ami a tanulmányi idő rövidítését jelentette. Igaz, hogy csak bizonyos szakmákra vonatkozott, de mégis 86 szakmában állította vissza a korábbi hároméves képzési időt. E lépésből már következett, hogy később a teljes szakmunkásképzésben is csökkenhet a képzési idő, ami 2013-ban be is következett ${ }^{5}$. Majd 2016-tól a korábbi szakképzési rendszer is megváltozott, a szakgimnáziumi képzésben ugyan nem rövidült a képzési idő ${ }^{6}$ csak átalakult, mivel korábban a szakközépiskolákban szakmai alapozó képzés folyt, és 13-15. évfolyamokon tanultak, szereztek szakmai végzettséget a tanulók. Ma sem szereznek ugyan OKJ végzettséget a szakgimnazisták, de jóval magasabb a szakmai tárgyak aránya a képzésben, és a végzettség bizonyos munkakör betöltésére jogosítja fel a tanulót. A szakmai tárgyak a közismereti tárgyak rovására növekedtek, melynek hátránya, hogy az általános kompetenciák fejlesztését szolgáló órák száma csökkent, valamint a szakgimnazisták már nem választhatják a felsőoktatás bármely szakját, csak a szakirányú továbbtanulás útja nyitott számukra. A szakképzés átalakulása mellett a 2011-es új köznevelési törvény ${ }^{7}$ számos területen hozott még változást, így például szigorította a szerkezetváltó és az ötéves képzéseket folytató iskolák müködését (a képzések működését bizonyos tanulói teljesítmény eléréséhez kötötte), illetve a tankötelezettséget 16 éves korra szállította le.

1993. évi LXXIX. törvény 1996. IX. 1-től hatályos szövege

1993. évi LXXIX. törvény 2003. évi módosítása

3 Egy 1996-os törvénymódosítás a tankötelezettség korhatárának 18 éves korra emelését az 1998-ban általános iskolába lépők számára tette kötelezővé.

4 A közoktatásról szóló 1993. évi LXXIX. törvény 2009. évi XLIX. törvénnyel történő módosításával az ún. „elörehozott” szakképzés jelent meg a szakiskolai képzés rendszerében, amelyet a módosított törvény 27. §-ának (4) új bekezdése határoz meg.

5 2011. évi CLXXXVII. törvény a szakképzésről

2015. évi LXV. törvény a nemzeti köznevelésről szóló 2011. évi CXC. törvény módosításáról

2011. évi CXC. törvény a nemzeti köznevelésről 


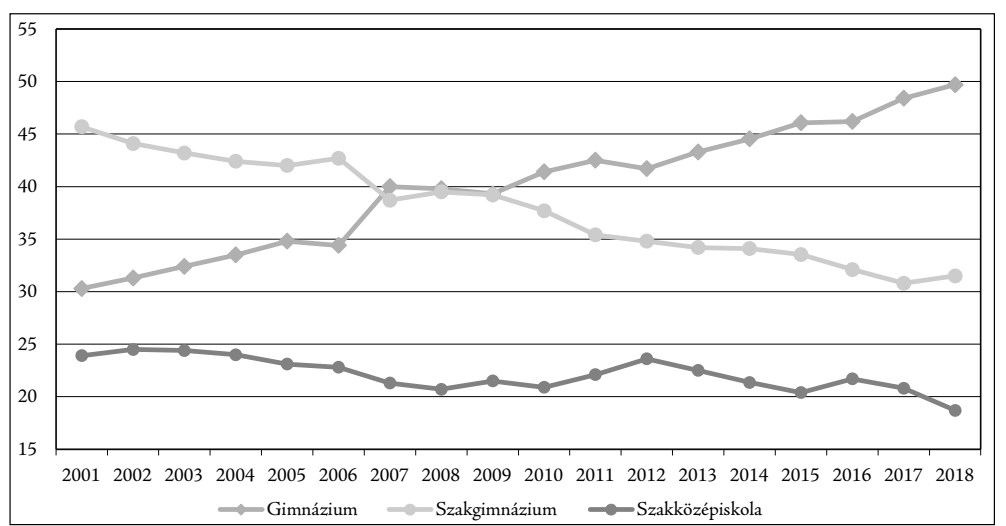

1. ábra: Hova jelentkezett első helyre, képzési típus szerint (\%) 2001-2018. Forrás: Középfokú Felsőoktatási Ionformációs Rendszer (KIFIR-adatbázis)

Látható tehát, hogy a három képzési út (gimnázium, szakgimnázium, szakközépiskola) más-más képzési idővel bír, így a 15-19 éves korosztály tanulásban való részvételi arányát nagyban befolyásolja, hogy a korosztályon belül melyik képzésben mennyien tanulnak. A középiskolai továbbtanulásról csak a kétezres évek eleje óta van információnk, a Köznevelési Felvételi Információs Rendszer tartja nyilván az adatokat. 18 év trendje alapján látható, hogy a tanulói/szülői preferenciák alapvetően az érettségit adó képzések felé irányulnak, majd a kétezres évek közepétől egyre nagyobb arányban fordulnak a gimnáziumok felé, megelőzve a szakközépiskolai (későbbi szakgimnáziumi) jelentkezéseket (1. ábra). Ennek vélhető oka a felsőoktatási továbbtanulási törekvésekben keresendő. 2018-ban már minden második tanuló a gimnáziumot választja. Ugyanakkor a felvettek arányát tekintve az tapasztalható, hogy a gimnázium jelentős szelekciós pont a magyar közoktatásban, amely társadalmi háttér alapján erősen determinált. 2018-ban több mint tízezer tanuló nem jutott be gimnáziumi képzésbe, így szakgimnáziumokban és szakközépiskolákban is többen tanulnak a jelentkezésekhez képest (2.ábra).

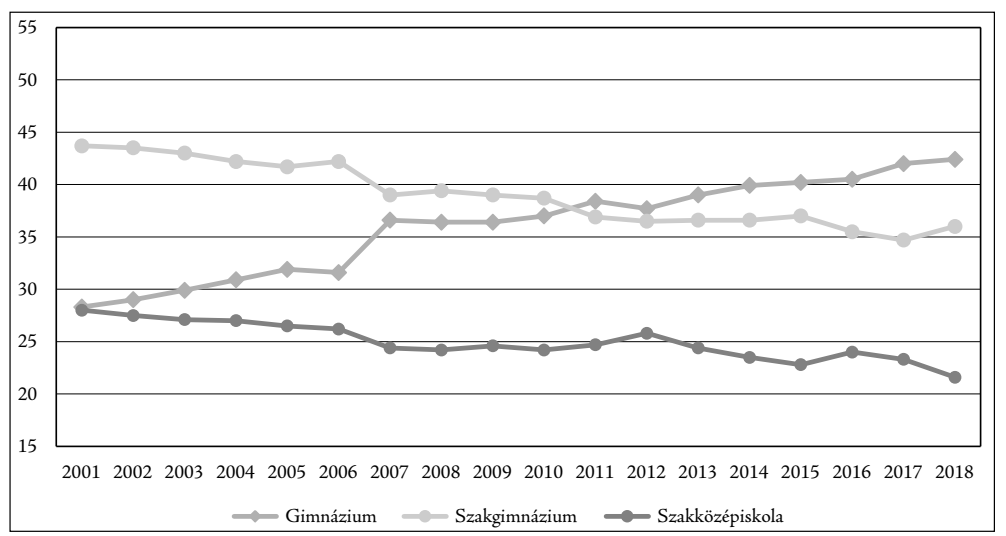

2. ábra: Hova vették fel, képzési típus szerint (\%) 2001-2018. Forrás: KIFIRadatbázis 
Összességében a tanulók 42\%-át vették fel gimnáziumi képzésbe, vagyis a korosztály nagyobb része szakképzésben kezdi meg tanulmányait, köztük minden ötödik tanuló szakközépiskolai képzésben.

A képzésben való részvételt az is befolyásolja, hogy mekkora az egyes képzési szinteken a lemorzsolódás. A lemorzsolódás kutatása - a középfokú képzés expanziójával együtt - a kilencvenes évek óta jelen van a magyar közoktatásban (Liskó 2003; Febérvári 2008; Kertesi-Kézdi 2010), a kétezres évektől pedig összekapcsolódott a korai iskolaelhagyás vizsgálatával (Mártonfi 2014), mivel az Európai Unió tagországaiban kiemelt céllá vált a korai iskolaelhagyás megakadályozása. Míg a lemorzsolódás az iskolarendszeren belüli továbbhaladásra vagy éppen megtorpanásra utal, addig a korai iskolaelhagyás az oktatási rendszer kimeneti eredményesség mutatója, azt jelzi, hogy a 18-24 éves korosztályon belül mekkora azok aránya, akik nem szereznek középfokú végzettséget $^{8}$. Az európai célérték 10\%, vagyis 2020-ig e százalékos érték alá kell szorítaniuk a tagországoknak a korai iskolaelhagyók arányát. Mindkét fogalmat tekintve, a legveszélyeztetettebb képzés a szakképzés, ezen belül a szakközépiskolai képzés, hiszen - ha évvesztéssel is - míg a gimnáziumból a szakgimnáziumba, a szakgimnáziumból a szakközépiskolába kerülhet át a tanuló, ha kudarc éri, addig a szakközépiskolából már nincs hová kerülnie, általában onnan már kikerülnek a tanulók az iskolarendszerből. 2014 óta van úgynevezett lemorzsolódási mutató ${ }^{~(F e h e ́ r v a ́ r i ~ 2015), ~ a m e l y ~ e g y ~ t a n e ́ v ~}$ változását alapul véve nézi azoknak az arányát, akiknek megszünt a tanulói jogviszonyuk és nem szereztek középfokú végzettséget. Az adatok szerint (2014-2016 között) már az általános iskolások egy százaléka kiesik az iskolarendszerből, hasonló az aránya a gimnáziumból lemorzsolódóknak (Varga 2018). Míg a szakgimnáziumokban 7-8\% körüli a lemorzsolódók aránya, addig a szakközépiskolákban ennek kétszerese, 15-17\% közötti. A HÍD-programokban tanulóknál háromból egy iskolaelhagyó. E magas arányokhoz a 16 éves korig tartó tankötelezettség is hozzájárul, illetve az, hogy a tanulói jogviszony megszűnése, megszüntetése könnyebbé válik 16 éves kor fölött (elegendő 30 órás igazolatlan hiányzás hozzá).

Az Unió ajánlása alapján 2016 óta korai jelzőrendszer ${ }^{10}$ is segíti a lemorzsolódás által veszélyeztetett tanulók azonosítását, illetve lehetőséget nyújt beavatkozások kezdeményezésére. Az Oktatási Hivatal által működtetett jelzőrendszer félévente ad arról információt, hogy hogyan alakul az általános iskola felső tagozatán és a középfokú képzésben a lemorzsolódás által veszélyeztetett tanulók aránya. 2019 első félévében a nappali képzésben 744159 tanuló 9,1\%-a számított veszélyeztetettnek (67918). Az országos átlagos arányt képviselik a szakgimnazisták (10,6\%). Az általános iskola felső tagozatán az átlagosnál magasabb a veszélyeztetettek aránya (12,6\%), de a legmagasabb

8 A korai iskolaelhagyás/végzettség nélküliség rátája az Európai Unióban hivatalosan használt definíció szerint azon 18-24 évesek arányát méri, akiknek nincsen középfokú (ISCED 3 szintű, szakmunkás vagy érettségi típusú) végzettsége, és nem is vesznek részt oktatásban vagy képzésben. A mutatót az Eurostat által koordinált éves, nagymintás munkaerő-felvétel alapján számítják. A mutató tulajdonképpen egy alsó becslés, hiszen a 18-24 éves, oktatásban részt vevők egy bizonyos hányada később sem fog középfokú végzettséget szerezni. Ráadásul a felmérés bármilyen, tehát nem végzettséghez vezető oktatásban való részvétel esetén sem sorol egy fiatalt a korai iskolaelhagyók közé.

9 Lemorzsolódott tanulónak tekintjük azt a tanulót, aki az előző év azonos napján a tanulói nyilvántartásban szerepelt, a tárgyév október 1-jén már nem volt a tanulói nyilvántartásban (megszűnt a tanulói jogviszonya), és nem szerzett középfokú végzettséget.

10 229/2012. (VIII. 28.) Korm. rendelet a nemzeti köznevelésről szóló törvény végrehajtásáról, 44 \$ J 
a szakközépiskolákban (18\%). Az átlagosnál jóval alacsonyabb a veszélyeztetett tanulók előfordulása a gimnáziumokban (2,6\%). A veszélyeztetettség iskolafenntartó szerinti és területi jellegzetességet is mutat. A szelekciós hatások révén a magán/alapítványi (8\%) és az egyházi $(8,9 \%)$ oktatásban a legalacsonyabb, míg a tankerületi $(10,5 \%)$ és egyéb állami (szakképző centrumok) (13,3\%) fenntartásban müködő iskolákban magasabb az arányuk. Területi szempontból Észak-Magyarország rendelkezik a legrosszabb mutatóval (16-18\%) és a főváros a legkedvezőbbel (7\%).

Mindezek az adatok már elörevetítik azt is, hogy a kimeneti indikátor sem mutat kedvező tendenciákat. A 3. ábra Magyarország és az Európai Unió korai iskolaelhagyóinak átlagát veti össze, melyből látható, hogy míg az Unióban magasabb átlagértékről indult a korai iskolaelhagyók aránya, és folyamatos csökkenés tapasztalható, addig Magyarországon inkább az ingadozás, stagnálás jellemezte a kétezres éveket, 2010 után pedig határozott növekedést mutat az arány. Magyarország 2013-ban lépett az uniós átlag fölé, ekkor haladta meg először a korai iskolaelhagyók aránya az uniós átlagot és azóta is fölötte van. Magyarország ezzel az aránnyal a 28 ország között a 23. helyen áll, Bulgária, Olaszország, Románia, Málta és Spanyolország zárja a sort 17,9\%-os aránnyal. (Bár megjegyezzük, Spanyolországban 2013-2018 között 5 százalékponttal csökkent a korai iskolaelhagyók aránya.) A legjobb mutatóval Horvátország és Szlovénia rendelkezik (3,3 és 4,2\%).

Területi szempontból hasonló jellemzőket tapasztalhatunk, mint a lemorzsolódással veszélyeztetettek esetében is, Közép-Magyarország és Nyugat-Dunántúl van a legkedvezőbb helyzetben, ott $10 \%$ alatti a korai iskolaelhagyók aránya. A legsúlyosabb helyzetben Észak-Magyarország van (19,3\%), ahol Közép-Magyarországhoz képest kétszeres a korai iskolaelhagyók aránya. Az Eurostat ${ }^{11}$ készített egy olyan elemzést is, amelyben azt vizsgálja meg, hogy hogyan oszlanak meg a korai iskolaelhagyók az urbanizáció szintje szerint a különböző országokban, elkülönítve a nagyvárosokat, városokat és rurális térségeket. Az elemzés szerint az Unió országai között Magyarországon, Bulgáriában és Romániában van a legnagyobb különbség a három kategória alapján, és e három országban a rurális térségeket sújtja leginkább a korai iskolaelhagyás problémája.

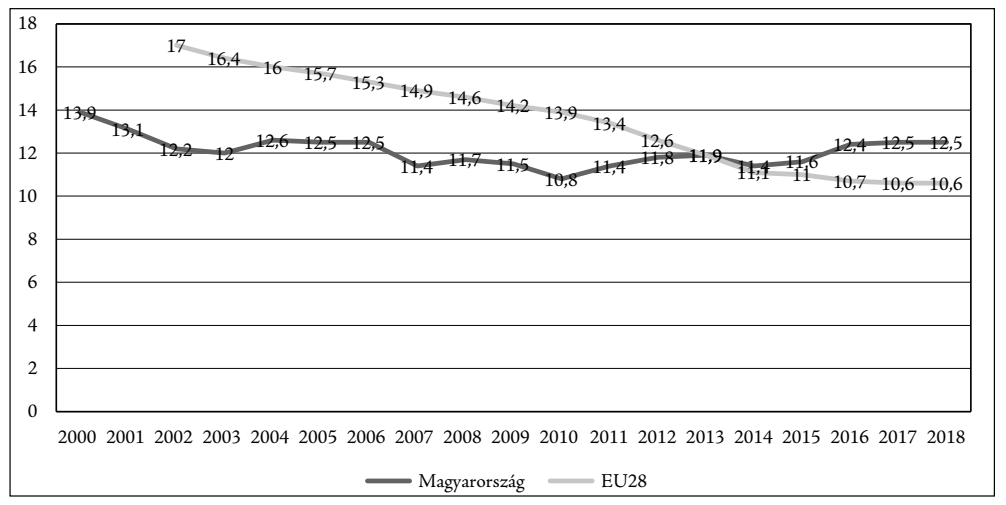

3. ábra: Korai iskolaelhagyás mutatója, 2000-2018. Forrás: Eurostat

11 https://ec.europa.eu/eurostat/statistics-explained/index.php/Early_leavers_from_education_and_ training\#Analysis_by_degree_of_urbanisation 


\section{Trendek a felsőoktatásban}

A tanulással töltött idő kitolódása és a hallgatói populáció életkor szerinti heterogenitása a felsőoktatásban is megfigyelhető. Napjainkban számos fejlett európai országban a 19-20 évesek legalább 40\%-a tanul a felsőoktatásban, de a 25 év feletti korosztálynak is mintegy 15\%-a. Egyes országokban az ennél idősebbek részvételi aránya is jelentős, jóllehet ez sok esetben nem feltétlenül jelent nappali képzést, hanem inkább részidős képzésben folytatott tanulmányokat. A részidős képzésben részt vevők aránya különösen egyes skandináv országokban magas (4. ábra).

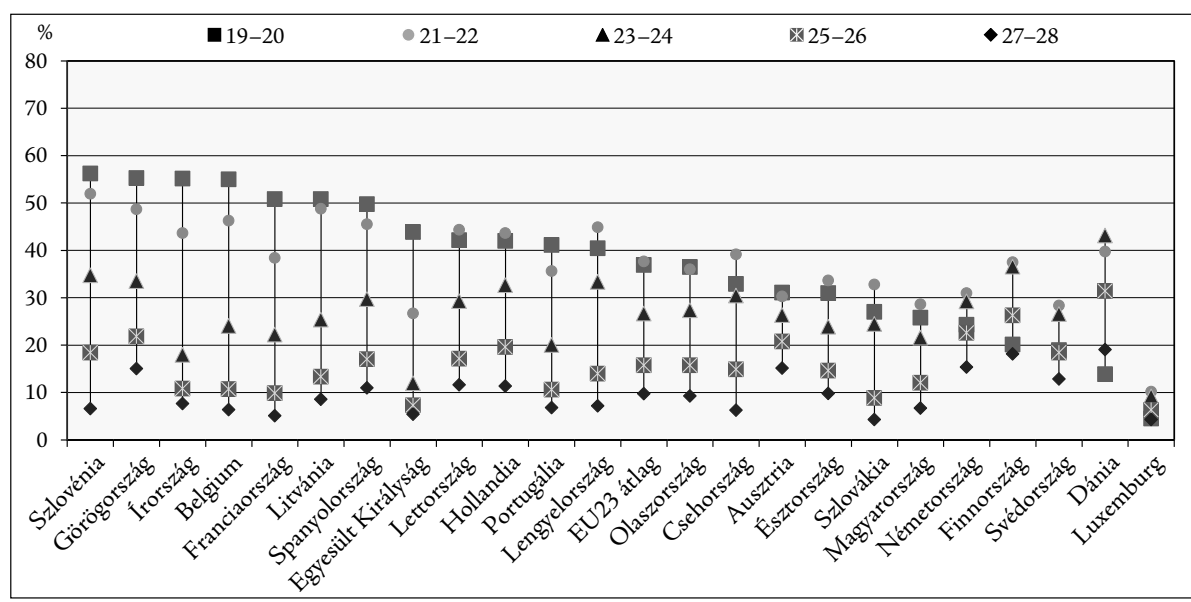

4. ábra: A felsőoktatásban részt vevő 19-28 évesek aránya (2017). Forrás: Education at a Glance 2019. OECD - Figure B1.1. Megjegyzés: Az ábrán az országok a 19-20 évesek részvételi arányának sorrendjében szerepelnek

Nem csupán a hallgatói átlagéletkor, hanem az újonnan belépők életkora is kitolódott, az alapképzést nemcsak Magyarországon, hanem más országokban is tipikusan 19-21 évesen kezdik a hallgatók a korábbi 18-19 éves kezdéshez képest. A hazai folyamatok ugyanezt mutatják: míg 2006-ban a nappali munkarendü alap-és osztatlan képzésekre jelentkezők 32\%-a 18 éves volt, s további 34\% 19 éves, addig 2018-ban a 18 évesek aránya

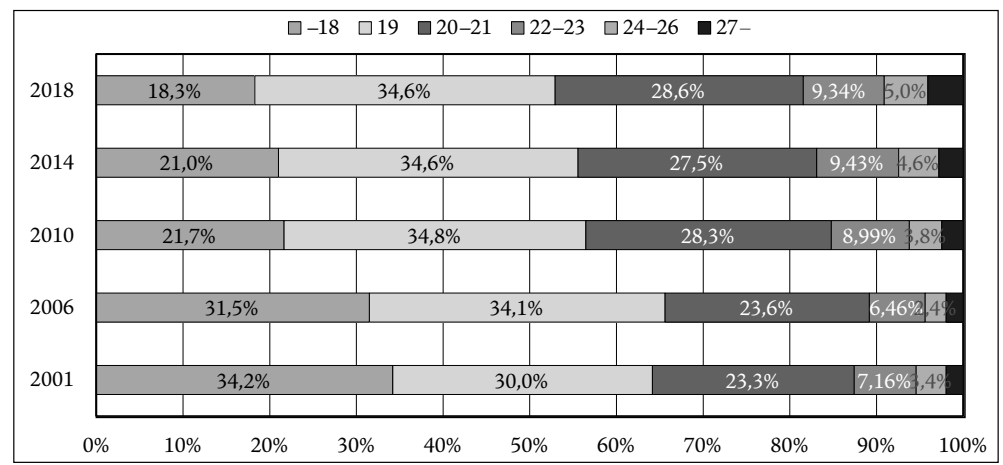

5. ábra: A jelentkezők életkori megoszlása alap- és osztatlan képzésben nappali munkarenden. Forrás: felvi.hu 
$18 \%$, a 19 éveseké 35\%, de emellett nagyobb arányban megjelennek a 20-21 éves új belépők, sőt a nem tipikus életkorú 24 év felettiek is. A részidős képzésekben még nagyobb azoknak az aránya, akik 25 évesen vagy annál idősebben kezdenek új felsőfokú tanulmányokat (5. ábra).

Ezt mutatják más megközelítésben az Eurostudent VI. felmérés adatai is, miszerint Magyarországon a hallgatók átlagéletkora 26 év (s ezzel az értékkel a vizsgált országok felső harmadába tartozik), a hallgatók $16 \%$-a pedig az érettségit követően több mint két évvel később került be a felsőoktatásba. Ez utóbbi adat egyébként nemzetközi összevetésben átlagosnak tekinthető, de az adatok részletesebb vizsgálata azt mutatja, hogy a felsőoktatásba való késleltetett továbblépés Magyarországon több mint kétszer olyan gyakori azok körében, akik kedvezőtlenebb iskolázottsági hátterü családokból érkeznek (24\%), mint azok körében, akiknek az apja felsőfokú végzettséggel rendelkezik (10\%). (Hauschildt-Vöglte-Gwosc 2018: 71.)

Az utóbbi évtizedekben a felsőoktatás intézményrendszerében is számottevő változás, diverzifikálódás következett be. Új intézménytípusok, új képzési programok kerültek kialakításra, s figyelemre méltó arányban jelentek meg atipikus hallgatói csoportok. Bár a legtöbb országban továbbra is a Bachelor képzésben részt vevők adják a hallgatók túlnyomó többségét, egyes országokban (pl. Ausztria, Spanyolország, Dánia) a rövid ciklusú képzési programok aránya is jelentős az új belépők körében (6. ábra).

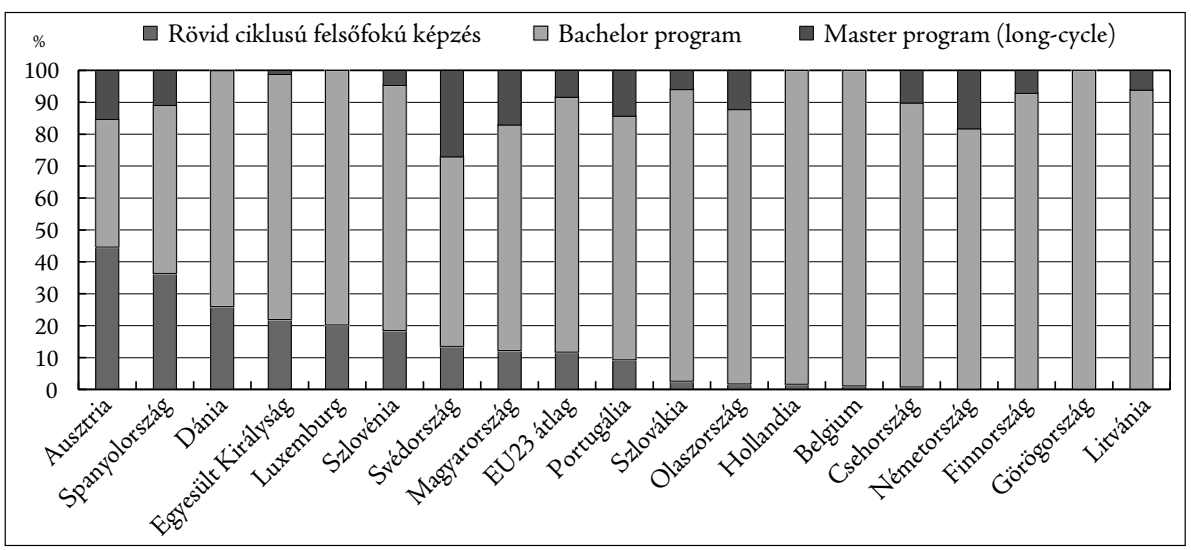

6. ábra: Az újonnan belépők megoszlása az elkezdett képzés szintje szerint. Forrás: Education at a Glance 2019. OECD - Figure B4.1.

Ezek a változások, illetve következményeik a hazai felsőoktatási rendszerben is megmutatkoznak, ahol az 1990-es években kezdődött expanzió mellett a bolognai képzési rendszerre való átmenet is jelentős hatással volt a hallgatói létszám és összetétel alakulására. Az expanzió nem egyformán érintette a nappali és a részidős képzéseket (a részidős képzésben meredekebb létszámemelkedés volt jellemzö), majd az expanzió lecsengésével és a bolognai képzési szerkezetre való áttéréssel új kihívásként az új képzéstípusok megjelenése és a korábbi képzések átalakulása hozott változást. Mindezeket időben elhúzódóan egy intézményrendszert érintő átalakulás is színezte.

A z expanzió és a szerkezeti átalakulás a hallgatói populációt tekintve több következménnyel is járt. Egyrészt a bekerülési esélyek növekedése miatt olyanok is bejutot- 
tak a felsőoktatásba, akik korábban nem feltétlenül kerültek volna be, másrészt jelentős különbségek maradtak, illetve új típusú eltérések jelentkeztek képzési területek, szakok és képzési programok, illetve munkarend és a tanulmányok finanszírozásának jellege szerint. A törésvonal tehát már nem annyira a felsőoktatásba való bekerülés kapcsán jelentkezett, hanem sokkal inkább a különböző képzési szintek, képzési formák és képzési területek között (Koucký-Bartušek-Kovařovic 2009).

A hazai adatok arra is rámutatnak, hogy a bekerülés tekintetében a középiskola típusa is meghatározó: a gimnáziumokban érettségizetteknek sokkal nagyobb az esélyük arra, hogy felsőfokon tanuljanak tovább (Veroszta 2012; Szemerszki 2014). Ez részben az önszelekcióval van összefüggésben, másrészt ugyanakkor az egyes szakokon, képzéseken megfigyelhető magasabb követelményekkel is, minek következtében a szakgimnáziumokban érettségizettek számára a nem ágazati továbbtanulás, illetve az esélynövelő többletpontok megszerzését feltételező képzésekre való bekerülés különösen nagy kihívást jelent. A jövőben bevezetésre kerülő emelt szintű érettségi vizsga, illetve nyelvvizsga-követelmény tovább nehezítheti egyes tanulói csoportok, köztük a szakgimnazisták helyzetét.

$\mathrm{A} z$ Eurostudent $\mathrm{V}$. hallgatói adatfelvétel magyarországi adatai azt mutatták, hogy 2013-ban 44 százalék volt azoknak a hallgatóknak az aránya, akiknek a szülei nem rendelkeztek felsőfokú végzettséggel, ugyanakkor az osztatlan képzések hallgatói között felülreprezentáltak voltak a felsőfokú végzettségű szülővel rendelkezők, s a mesterképzéseken is arányaiban több a felsőfokú végzettségű szülővel rendelkező, mint alapképzésben. A nappalisok 53, a részidős képzésre járók mindössze 36 százaléka rendelkezett legalább egy diplomás szülővel (Garai-Kiss 2014).

A tanulmányok melletti munkavégzés ténye, illetve a munkavégzés jellege tovább színesíti a hallgatók belső rétegzettségét, ami a tanulási utakra is kihatással van. Az szinte természetesnek vehető, hogy a részidős képzésekre járók túlnyomó többsége dolgozik az Eurostudent VI. felmérés adatai szerint $87 \%$-uk a tanulmányi időszakban is -, de a nappali munkarendủek több mint ötödének is van állandó jellegű munkája, s emellett még csaknem ugyanennyien dolgoznak alkalomszerüen a tanulmányi időszakban (Hámori-Horváth 2018).

A munkavégzés okait vizsgálva a kutatások leginkább a szociális különbségekre mutatnak rá (a kényszerü munkavállalók aránya a rosszabb anyagi helyzetüek között a legmagasabb), s heterogén képet rajzolnak fel a munkavégzés hallgatói életútra gyakorolt hatásait illetően. Az elemzések azt mutatják, hogy a hatások leginkább a munkavégzés intenzitásával és a munka jellegének tanulmányokhoz való kapcsolódásával vannak öszszefüggésben. A hazai adatok szerint a tanulmányokhoz illeszkedő munkavégzés pozitívan befolyásolja a képzés sikerességét, a továbbtanulási szándékot (Veroszta 2014; Hámori-Horváth-Veroszta 2018), illetve a későbbi munkavállalás sikerességét is (Gáti-Róbert 2013), míg a tanulmányokhoz nem kapcsolódó (kényszerű) munkavégzés hosszabb távú hatása inkább negatív, fóként, ha az magas intenzitással párosul.

Amint láttuk, az elözőekben vázolt változások nem csupán a hallgatói populáció öszszetételére, hanem a felsőoktatási tanulási utakra is befolyással bírnak. Nem véletlen, hogy az utóbbi időben fokozott figyelem irányul a hozzáférés növelése mellett a bent maradásra, a végzési arányok növelésére. Az egyéni és nemzetgazdasági szintű megtérülés, a foglalkoztatottsági esélyek javítása mellett az Európai Unió 2020-as célkitüzése - nevezetesen, hogy a 30-34 éves korosztályban a diplomások aránya érje el a 
40\%-ot (Magyarország esetében a célérték 34\%) - is egy indirekt eszköznek tekinthető a végzési arányok növelésére.

Mindemellett a felsőoktatási intézményrendszernek, ezen belül maguknak az egyes intézményeknek is alkalmazkodniuk szükséges a megváltozott hallgatói összetételhez. Különös figyelmet érdemelnek azok a hallgatói csoportok, amelyek valamilyen ok miatt (hiányos, elégtelen előzetes tudás, anyagi, szociális, családi vagy kulturális okok következtében) fokozottabban kitettek a lemorzsolódásnak. A hallgatói lemorzsolódás (illetve annak komplementer fogalma, a hallgatói sikeresség) és a mögöttes háttértényezők az 1970-es évek közepe óta egyre intenzívebben vizsgált terület. Többféle megközelítés mentén többféle modell került kidolgozásra és fokozatos finomításra a lemorzsolódás okainak beazonosítása érdekében. A modellek sokfélesége és fokozatos finomítása érthető, ha figyelembe vesszük, hogy a lemorzsolódás egy olyan komplex jelenség, amely mögött számos tényező (egyéni, pszichológiai, szociális, társas-kulturális, intézményi stb.) állhat, sok esetben egymással is kölcsönhatásban. De nemcsak a modellek sokfélesége érdemel figyelmet, hanem a felsőfokú tanulásban való előrehaladást körülíró fogalmak komplexitása is, beszéljünk sikeres végzésröl, lemorzsolódásról vagy bennmaradásról (Miskolczi-Bársony-Király 2018; Kerülö 2018). A felsőoktatásban ezek több szinten és több nézőpontból is értelmezhető fogalmak, s csak a nézőpontok tisztázása után vehető alaposabban górcső alá a jelenség, és csak annak ismeretében azonosíthatók a problémák és fogalmazhatók meg javaslatok.

A lemorzsolódás csökkentését célzó jó gyakorlatok között a 2018, évi Bologna Report többek között olyanokat sorol fel, mint a lemorzsolódás szempontjából különösen veszélyeztetett elsőévesek fokozott segítése mentori programok, tanulástámogató eszközök révén, a hallgatók szabályozási eszközökkel történő ösztönzése és motiválása tanulmányaik időben való befejezésére (pl. bizonyos juttatásokhoz a félévente minimálisan szerzendő kreditszámok előírása), vagy az egyes alulreprezentált hallgatói csoportok számára nyújtott extra segítség. Emellett esetenként a felsőoktatási intézményeket is ösztönzik arra, hogy fokozzák a hallgatói bennmaradást például különböző finanszírozási eszközök, szabályozások révén. Ez utóbbinak ugyanakkor lehetnek kockázatai is, amennyiben a magasabb lemorzsolódási kockázatú hallgatói csoportok nem feltétlenül egyenletesen oszlanak meg az intézmények között, amint erre az adatok hazai viszonylatban is mutatnak (Polónyi 2018).

Az utóbbi néhány évben Magyarországon is egyre több kutatás és egyre pontosabb adatok állnak rendelkezésre a végzési és továbbtanulási arányok, illetve a lemorzsolódás jelenségének vizsgálatához. A legtöbb ilyen kutatás továbbra is intézményi szintü, vagy az egyes képzési területek (ezen belül a képzési szint és a munkarend) sajátosságainak megragadására irányul. Az elöbbi nem véletlen, hiszen a hallgatói lemorzsolódás az intézmények számára különösen fájó veszteség, ráadásul sok esetben azonosíthatók olyan okok, amelyek komplex intézményi beavatkozásokkal sikeresen kezelhetők. A képzésterületi kiindulópont pedig azért érdemel figyelmet, mert a felsőoktatás bonyolult rendszerében szükség van olyan fix pontokra, amelyek összehasonlíthatóvá tesznek végzési és lemorzsolódási adatokat. Az egyik ilyen a képzési terület, hiszen a hallgatói életutakat, karrierterveket a képzési területek szerint igencsak eltérő munkaerőpiaci folyamatok is erőteljesen befolyásolják. Az országos és a képzésterületi, munkarend szerinti tendenciák, sajátosságok bemutatására a FIR adatok, illetve a FIR-rel összekapcsolt egyéb adminisztratív adatbázisok kiváló lehetőséget nyújtanak 
az utóbbi években. Ezek eredményei már kereshető és szűrhető adatok formájában is elérhetők.

Mindazonáltal még mindig kevés az olyan követéses vizsgálat, amelyik egy-egy belépő kohorsz paneladatán alapul, s a sikeres végzés, illetve a lemorzsolódás hátterében megbúvó okok széles körének feltárására alkalmas. Az adminisztratív adatok összekapcsolásával létrejövő adatbázisok nyilvánvalóan korlátozott adatkörre terjedhetnek ki, a hallgatói életútvizsgálatokban nagy jelentőségük van éppen ezért továbbra is a kérdöíves adatfelvételeknek. S nagy szerepük van azoknak a kutatásoknak is, amelyek a korábbi iskolafokok eredményeinek előrejelző képességét vizsgálják, paneladatok vagy panelvizsgálatok segítségével, beazonosítva olyan háttérváltozókat, amelyek például már a középiskolában fejleszthetők a sikeres felsőfokú tanulmányok érdekében, a későbbi lemorzsolódás csökkentése céljából.

\section{Összegzés}

Az írás e tematikus szám bevezető tanulmányaként áttekintette a közoktatás és a felsőoktatás főbb hazai és nemzetközi trendjeit. Megállapítható, hogy a közoktatás tekintetében a magyar trendek a nemzetközivel nagyon hasonlóan alakultak 2009-ig, vagyis egy-egy korosztály egyre nagyobb hányada egyre több időt töltött a közoktatásban. A középfokú expanzió hatásaként azonban a kétezres évek elejétől problémaként jelent meg a lemorzsolódás, főleg az alacsonyabb státuszú szülők gyermekeinek körében. Ugyanakkor erre a helyzetre megoldási lehetőséget jelentett a tankötelezettségi kor kiterjesztése, ez a rendelkezés épp a legkedvezőtlenebb társadalmi, gazdasági státuszú szülők gyermekeinek adott lehetőséget a középfokú végzettség befejezésére. 2009 után - szakpolitikai beavatkozások révén - fokozatosan szükült a középfokú képzésben egyes képzések képzési ideje és egy korosztályon belül a képzésben lévők aránya, így a nemzetközi, európiai trendekhez képest egy ellentétes folyamat indult meg, amelynek az is a következménye, hogy növekszik egy korosztályon belül a középfokú végzettséget nem szerzők aránya.

A z 1990-es években kezdődött felsőoktatási expanzió Magyarországon is látványosan megnövelte a felsőoktatásban részt vevők számát és korosztályi arányát, miközben a felsőoktatás diverzifikálódásával együtt hozzájárult a hallgatói heterogenitás növekedéséhez. A hallgatói populáció sok szempontú belső rétegzettsége a tanulmányokban való elörehaladás szempontjából is kitüntetett figyelmet érdemel, hiszen a végzési arányok növelése hazai és nemzetközi viszonylatban egyaránt prioritás, számos ország küzd az időben túlfutó képzések vagy a lemorzsolódás problémájával. Nem véletlen, hogy a hallgatói életutakkal kapcsolatos kutatások az utóbbi években itthon is a vizsgálódások középpontjába kerültek, ami részben annak is köszönhető, hogy a felsőoktatási, illetve a végzés utáni pályautak vizsgálatához egyre több és egyre jobb minőségü adat áll rendelkezésre. A kutatások segítenek a problémás pontok beazonosításában, $\mathrm{s}$ az eredményekre alapozva fejlesztési javaslatok fogalmazhatók meg intézményi vagy országos szinten. 


\section{IRODALOM}

Adamecz-Völgy i A. (2018) Increased Compulsory School Leaving Age Affects Secondary School Track Choice and Increases Dropout Rates in Vocational Training Schools. Budapesti Munkagazdaságtani Füzetek (BWP) 2018/1.

Gáвог K. (2004) Globalizáció és ifúsági korszakváltás. In: GÁвог K. \& Jancsáк Cs. (eds) Ifjúsági korszakváltás. Ifjúság az új évezredben. Szeged, Belvedere. pp. 28-72.

GÁвов K. (2012) Válogatott ifjúságszociológiai tanulmányok. Budapest, Új Mandátum Könyvkiadó.

Garai O. \& Kiss L. (2014) EUROSTUDENT V. Kutatási jelentés. Educatio Nonprofit $\mathrm{Kft}$.

GÁti A. \& Róbert P. (2013) Munkavállalás a tanulás mellett: kényszerűség vagy befektetés? In: Garai O. \& Veroszta Zs. (eds): Frissdiplomások 2011. Budapest, Educatio Társadalmi Szolgáltató Nonprofit Kft. pp. 93-110.

European Commission/EACEA/Eurydice (2018) The European Higher Education Area in 2018: Bologna Process Implementation Report. Luxembourg, Publications Office of the European Union.

Fenérvári A. (2008, ed.) Szakképzés és lemorzsolódás. Budapest, Oktatáskutató és Fejlesztő Intézet. (Kutatás Közben 283.)

Fehérvári A. (2015) Lemorzsolódás és a korai iskolaelhagyás trendjei. Neveléstudomány, Vol. 3. No. 3. pp. 31-47.

Hámori Á. \& Horváth Á. (2018) A felsőoktatás szociális dimenziója Magyarországon. EUROSTUDENT VI. gyorsjelentés. Budapest, Oktatási Hivatal.

Hámori Á., Horváth Á. \& Veroszta Zs. (2018) A tanulmányok melletti munkavállalás háttere és hatása a továbbtanulási tervekre. In: HÁMORI Á. (ed.): Eröforrások, eredmények és élmények a felsőoktatásban. Az EUROSTUDENT VI. nemzetközi hallgatói kutatás magyarországi eredményei. Budapest, Oktatási Hivatal.

Hauschildt, K., Vögtre, E. M. \& Gwosc, C. (2018) Social and Economic Conditions of Student Life in Europe. EUROSTUDENT VI. 2016-2018. Synopsis of Indicators. Bielefeld, Bertelsmann Verlag.

JАNCSÁ K Cs. (2013) Ifjúsági korosztályok korszakváltásban. Budapest, Új Mandátum Könyvkiadó.

Kertesi G. \& Kézdi G. (2010) Iskolázatlan szülők gyermekei és roma fiatalok a középiskolában. Beszámoló az Educatio Életpálya-felmérésének 2006 és 2009 közötti hullámaiból. In: Kolosi T. \& Tóth I. Gy. (eds) Társadalmi Riport 2010.

KERÜLő J. (2018) „Menni vagy maradni?” Lemorzsolódás a felsőoktatási intézményekben, okok és megoldási javaslatok. In: Pusztai G. \& Szigeti F. (eds) Lemorzsolódás és perzisztencia a felsőoktatásban. Debrecen, Debreceni Egyetemi Kiadó. pp. 170-188.

Koucký, J., Bartůšex, A. \& Kovařovic, J. (2009) Who is More Equal? Access to Tertiary Education in Europe. Prague, Charles University, Faculty of Education.

Liskó I. (2003) Kudarcok a középfokú iskolákban. Budapest: Oktatáskutató Intézet. (Kutatás Közben 250.)

Mártonfi Gy. (2014) Korai iskolaelhagyás - Hullámzó trendek. Educatio, Vol. 23. No. 1. pp. 36-49.

Miskolczi P., Bársony F. \& Király G. (2018) Hallgatói lemorzsolódás a felsőoktatásban: elméleti, magyarázati utak és kutatási eredmények összefoglalása. Iskolakultúra, Vol. 28. No. 3-4. pp. 87-105. 
OECD (2008) Education at a Glance 2008: OECD Indicators. Paris, OECD Publishing.

OECD (2019) Education at a Glance 2019: OECD Indicators. Paris, OECD Publishing.

PolóNyi I. (2018) A hátrányos helyzetű régiók felsőoktatási rekrutációjának néhány sajátossága. In: Pusztai G. \& Szigeti F. (eds) Lemorzsolódás és perzisztencia a felsőoktatásban. Debrecen, Debreceni Egyetemi Kiadó. pp. 207-224.

Somlai P. (2010) Változó ifúság. Educatio, Vol. 19. No. 2. pp. 175-190.

Szemerszir M. (2014) A középiskolából a felsőoktatásba - Jelentkezési és felvételi tendenciák. Felsőoktatási Mübely, Vol. 8. No. 1.pp. 47-63.

Tóт É. (1996) Világbanki szakképzési modell. Educatio, Vol. 5. No. 1. pp. 40-49.

VARGA J. (2018, ed.) A közoktatás indikátorrendszere 2017. MTA Közgazdaság- és Regionális Tudományi Kutatóközpont.

Veroszta Zs. (2012) A felsőoktatás különböző szintjeire felvettek jellemzői. In: Szemerszki M. (ed.): Az érettségitöl a mesterképzésig: Továbbtanulás és szelekció. Budapest, Oktatáskutató és Fejlesztő Intézet. pp. 51-82.

Veroszta Zs. (2014) Kinek meddig tart a felsőoktatás? A tanulmányok alatti munkavállalás továbbtanulási tervekre gyakorolt hatása. In: Kiss L. (ed.) A felsőoktatás szociális dimenziója. A Eurostudent $V$ magyarországi eredményei. Budapest, Educatio Társadalmi Szolgáltató Nonprofit Kft. pp. 53-66.

Zinnecker, J. (1992) Gyermekkor, ifúság és szociokulturális változások a Német Szövetségi Köztársaságban. In: Gáвов K. (ed.) Civilizációs korszakváltás és ifjúság: a kelet-és nyugat-európai ifjúság kulturális mintái. Szeged, József A. Tudományegyetem. pp. 29-48.

A cikk a Creative Commons Attribution 4.0 International License (https://creativecommons.org/licenses/ by/4.0/) feltételei szerint publikált Open Access közlemény, melynek szellemében a cikk bármilyen médiumban szabadon felhasználható, megosztható és újraközölhető, feltéve, hogy az eredeti szerző és a közlés helye, illetve a CC License linkje és az esetlegesen végrehajtott módosítások feltüntetésre kerülnek. (SID_1) 